\title{
KONSEP TARGHIB DAN TARHIB DALAM PERSPEKTIF TEORI BELAJAR BEHAVIORISTIK
}

\author{
Benny Kurniawan \\ Institut Agama Islam Nahdlatul Ulama Kebumen \\ e-mail:benny.wawan@yahoo.com
}

\begin{abstract}
Abstrak
Tulisan ini membahas tentang konsep imbalan dan ancaman atau targhib dan tarhibsebagaimana ayat-ayat al Qur'an sebagian memuat pernyataan-pernyataan yang bersifat menjanjikan imbalan atau hadiah dan bersifat mengancam atau memberi hukuman. Dalam teori pembelajaran behavioristik, pemberian hadiah dan hukuman disebut sebagai bagian dari faktor yang mempengaruhi proses dan hasil pembelajaran. Hasil dari tulisan ini menemukan bahwa konsep targhib dan tarhib dalam teori belajar behavioristik diposisikan sebagai stimulus atau rangsangan yang memberikan pengaruh terhadap motivasi pembelajaran dan tercapainya tujuan pembelajaran yang ingin dicapai. Namun ada sisi perbedaan antara konsep targhib dan tarhid dengan kajian teori behavioristik. Jika teori behavioristik hanya merupakan kajian ilmiah terhadap perilaku yang bersifat observabledan capaian tujuan pembelajarannya hanya bersifat duniawi. Berbeda dengan itu, nilai-nilai yang terkandung dalam pernyataan imbalan (targhib) dan ancaman (tarhib) mempunyai konsekwensi keimanan terhadap kebenaran yang bersifat non observable yaitu mengenai realitas akhirat sebagaimana sebagian besar merupakan isi dari pernyataan targhib dan tarhib.
\end{abstract}

Kata kunci: targhib, tarhib, behavioristik, pendidikan 


\section{A. Pendahuluan}

Al Qur'an sebagai kitab suci umat Islam merupakan kalam Allah yang bersama Sunnah merupakan pedoman hidup bagi manusia yang memuat segala norma dalam setiap sendi kehidupannya. Dengan adanya Al Qur'an dan Sunnah sebagai undang-undang yang diterbitkan oleh Sang Kholik sebagai paket dari penciptaanNyatersebut, maka sebagai Khalifatullah fi al-ard diberikan tanggung jawab untuk memberikan kemakmuran pada bumi. Sebagai pedoman normatif, Al Qur'an dalam membimbing manusia memberlakukan sistem reward and punishment sebagaimana terdapat dalam banyak ayat yang menunjukkan pemberian janji berupa hadiah-hadiah dan ancaman-ancaman agar manusia dalam berperilaku tetap pada garisnya dalam mengemban amanat tersebut.

Janji akan adanya imbalan atau hadiah yang sifatnya memberikan kepuasan terhadap kebutuhan fisik maupun psikhis manusia diberikan jika manusia menaati apa yang telah ditetapkan Allah dalam aturan-aturannya, sedangkan janji yang bersifat ancaman atau pemberian hukuman yang pedih dan menggambarkan penderitaan diberikan jika manusia menyeleweng dari aturan tersebut. Konsep mengenai hadiah dan ancaman yang terkandung dalam ayat-ayat Al Qur'an tersebut oleh Al Nahlawi disebut dengan Targhib dan Tarhib.

Terlepas dari gambaran indahnya hadiah dan pedihnya ancaman dalam ayat-ayat Al Qur'an, ternyata dari sudut pandang psikologi, hadiah dan ancaman memberikan pengaruh yang nyata terhadap perilaku manusia. Skinner menyebutnya dengan istilah positive reinforcement (penguatan positif) dan negative reinforcement (penguatan negatif). Hal ini yang kemudian dikembangkan menjadi teori belajar yang dikenal dengan teori belajar behavioristik.

Makalah ini bermaksud untuk menyandingkan teori belajar behavioristik dengan konsep targhib dan tarhib dalam ayat-ayat Al Qur'an.

\section{B. Targhib dan Tarhib}

Secara etimologis, kata targhib diambil dari kata kerja raghaba yang berarti menyenangi, menyukai dan mencintai. Kemudian kata itu diubah 
menjadi menjadi kata benda targhib yang mengandung makna Suatu harapan utuk memperoleh kesenangan, kecintaan, kebahagiaan. Semua itu dimunculkan dalam bentuk janji-janji berupa keindahan dan kebahagiaan yang dapat merangsang seseorang sehingga timbul harapan dan semangat untuk memperolehnya. Secara psikologis, cara itu akan menimbulkan daya tarik yang kuat untuk menggapainya. Sementara itu istilah tarbib berasal dari kata rahhaba yang berarti menakut- nakuti atau mengancam. Lalu kata itu diubah menjadi kata benda tarhib yang berarti ancaman hukuman. ${ }^{1}$ Menurut pengertian lain Targhib memiliki arti mendorong atau memotivasi diri untuk mencintai kebaikan. ${ }^{2}$ Tarhib diartikan menimbulkan perasaan takut yang hebat kepada orang lain. ${ }^{3}$

Abdurrahman an-Nahlawi mengemukakan, Targhib adalah janji yang disertai dengan bujukan dan membuat senang terhadap sesuatu maslahat,kenikmatan atau kesenangan akhirat yang pasti baik, serta bersih dari segala kotoran yang kemudian diteruskan dengan melakukan amal saleh dan menjauhi kenikmatan sepintas yang mengandung bahaya atau perbuatan yang buruk. ${ }^{4}$ Sedangkan Tarhib adalah ancaman dengan siksaan sebagai akibat melakukan dosa atau kesalahan yang dilarang Allah SWT, atau akibat lengah dalam menjalankan kewajiban yang diperintahkan Allah, dengan kata lain Tarhib adalah ancaman dari Allah yang dimaksudkan untuk menumbuhkan rasa takut pada hambanya dan memperlihatkan sifat-sifat kebesaran dan keagungan Ilahiyah, agar mereka selalu berhati-hati dalam bertindak serta melakukan kesalahan dan kedurhakaan. ${ }^{5}$

Targhib dan Tarhib didasarkan pada fitrah yang diberikan Allah kepada manusia, seperti keinginan terhadap kekuatan, kenikmatan, kesenangan hidup dan kehidupan abadi yang baik serta ketakutan akan kepedihan, kesengsaraan dan kesudahan yang buruk. ${ }^{6}$ Al Qur'an menggunakan Targhib dan Tarhib untuk membangkitkan motivasi agar beriman kepada Allah dan rasulnya,

\footnotetext{
Syahidin, Metode Pendidikan Qur'ani Teori dan Afikasi,(Jakarta, Misaka galiza, 1999) hal. 121

Muhammad Thalib, Pendidikan Islam metode 30 T,(Bandung : Irsyad Baitus Salam 1996) hlm. 96.

Ibid., hlm 156

Abdurrahman an-Nahlawi, Ushulut Tarbiyatil Islamiyah wa Aslibuha, terj. Herry Noer Ali,Prinsipprinsip dan metode Pendidikan Islam, (Bandung : Diponegoro, 1992) hlm 412.

Ibid.

Ibid, hlm 410 .
} 
mengikuti ajaran Islam, melaksanakan ibadah wajib, menjauhi maksiat dan hal yang dilarang oleh Allah dan berpegang pada istiqomah dan takwa. ${ }^{7}$

Dari berbagai pengertian di atas dapat diambil suatu pengertian bahwa, Targhib adalah janji akan suatu imbalan yang bersifat memberikan maslahah, kenikmatan, dan menyenangkan sebagai ganjaran atas amal shaleh manusia. Sedangkan Tarhib adalah janji yang berupa ancaman yang menyakitkan dan pedih dengan memperlihatkan kebesaran dan keMaha Kuasaan Allah agar manusia tidak melakukan kesalahan di dunia dengan melanggar aturan-atuan yang telah ditetapkanNya.

\section{Ayat-ayat Tentang Targhib dan Tarbib}

Dalam Al Qur'an banyak ayat yang isinya menyatakan ganjaran atau imbalan yaitu dengan memberikan janji-janji yang menggambarkan keindahan, kenikmatan, dan hal-hal yang bersifat memuaskan kebutuhan fisik maupun psikhis manusia, baik yang akan di peroleh manusia di alam dunia maupun yang dijanjikan di syurga. Hadiah atau imbalan tersebut dijanjikan kepada manusia yang mengikuti hukum-ketetapan Allah yaitu yang melaksanakan apa yang di perintahkan atau diperbolehkan Allah ketika menjalankan kehidupannya di dunia. Selain ayat-ayat yang menyatakan Targhib ( ganjaran), dalam Al Qur'an juda memuat ayat-ayat yang bersifat sebaliknya, yaitu menyatakan ancaman-ancaman atau hukuman (Tarhib). Ayat-ayat tarhib mengandung ancaman-ancaman bagi manusia dengan menggambarkan penderitaan-penderitaan yang akan dirasakan oleh manusia sebagai hukuman atas pelanggaran manusia terhadap ketentuan-ketentuan yang digariskan oleh Allah SWT dalam menjalani kehidupannya di dunia.

a. Ayat-ayat tentang Targhib

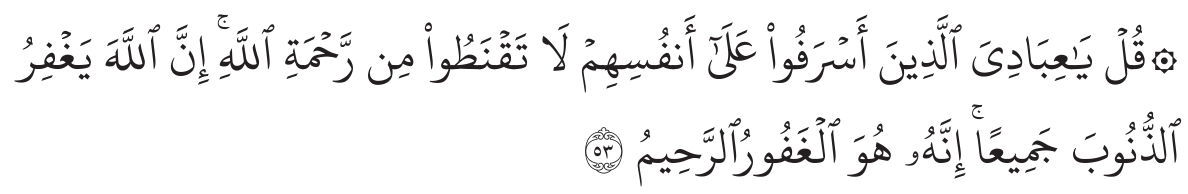

Muhammad Usman Najati, Belajar EQ dan SQ dari Sunnah Nabi, Terj. Irfan Salim, (Jakarta : Hikmah, 2002), hlm. 156. 
Katakanlah: "Hai hamba-hamba-Ku yang malampaui batas terhadap diri mereka sendiri, janganlah kamu berputus asa dari rahmat Allah. Sesungguhnya Allah mengampuni dosa-dosa] semuanya. Sesungguhnya Dialah yang Maha Pengampun lagi Maha Penyayang. (QS. Az Zumar ayat 53)

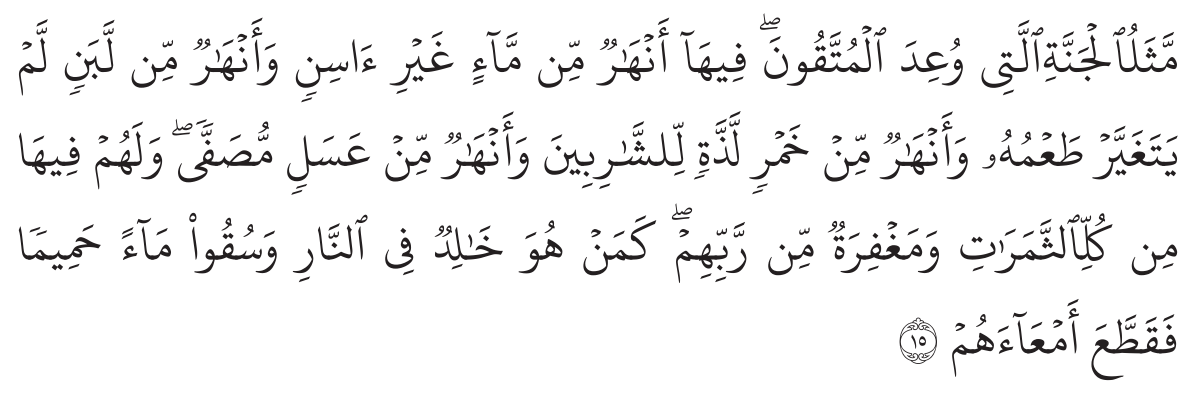

(apakah) perumpamaan (penghuni) jannah yang dijanjikan kepada orangorang yang bertakwa yang di dalamnya ada sungai-sungai dari air yang tiada beubah rasa dan baunya, sungai-sungai dari air susu yang tidak beubah rasanya, sungai-sungai dari khamar yang lezat rasanya bagi peminumnya dan sungai-sungai dari madu yang disaring; dan mereka memperoleh di dalamnya segala macam buah-buahan dan ampunan dari Rabb mereka, sama dengan orang yang kekal dalam Jahannam dan diberi minuman dengan air yang mendidih sehingga memotong ususnya? (QS Muhammad: $15)$.

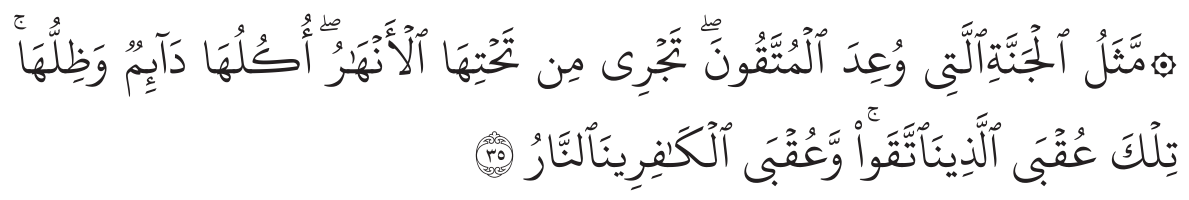

Perumpamaan syurga yang dijanjikan kepada orang-orang yang takwa ialah (seperti taman); mengalir sungai-sungai di dalamnya; buahnya tak hentihenti sedang naungannya (demikian pula). Itulah tempat kesudahan bagi orang-orang yang bertakwa, sedang tempat kesudahan bagi orang-orang kafir ialah neraka. (QS ar-Rardu: 35).

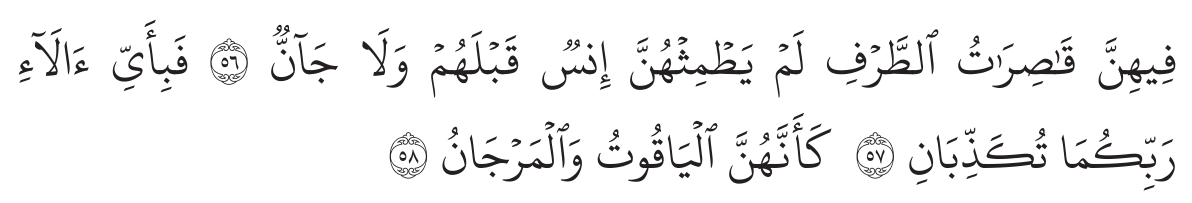


Di dalam syurga itu ada bidadari-bidadari yang sopan menundukkan pandangannya, tidak pernah disentuh oleh manusia sebelum mereka (penghuni-penghuni syurga yang menjadi suami mereka), dan tidak pula oleh jin. Maka nikmat Tuhan kamu yang manakah yang kamu dustakan. Seakan-akan bidadari itu permata yakut dan marjan. (Qs. Ar-Rahman: 56-58)

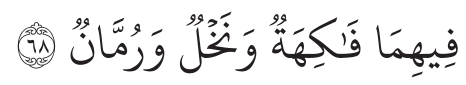

Di dalam keduanya (ada macam-macam) buah-buahan dan kurma serta delima. (Qs. Ar-Rahman:68)

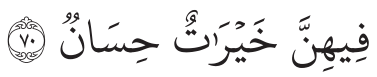

Di dalam syurga itu ada bidadari-bidadari yang baik-baik lagi cantikcantik. (Qs. Ar-Rahman: 70)

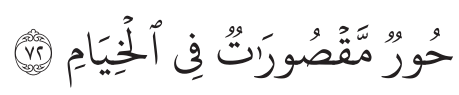

(Bidadari-bidadari) yang jelita, putih bersih, dipingit dalam rumah. (Qs. Ar-Rahman: 72)

b. Ayat-ayat tentang Tarbib
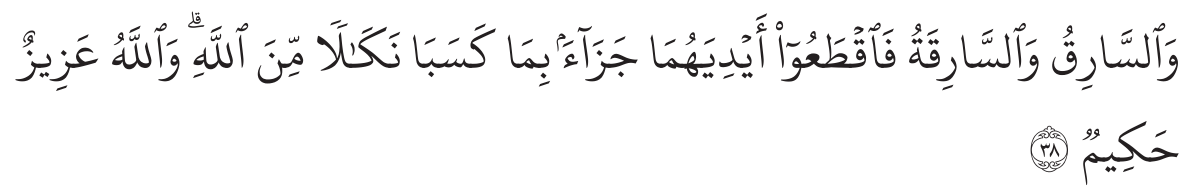

Laki-laki yang mencuri dan perempuan yang mencuri, potonglah tangan keduanya (sebagai) pembalasan bagi apa yang mereka kerjakan dan sebagai siksaan dari Allah. dan Allah Maha Perkasa lagi Maha Bijaksana.(QS. Al Ma'idah:38)

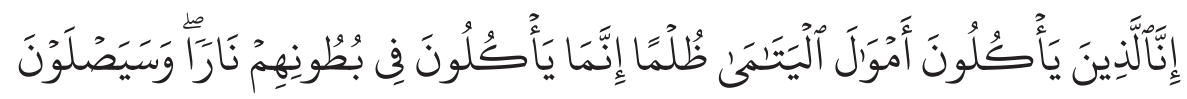


Sesungguhnya orang-orang yang memakan harta anak yatim secara zalim, sebenarnya mereka itu menelan api sepenuh perutnya dan mereka akan masuk ke dalam api yang menyala-nyala (neraka). (QS. An Nisaa:10)

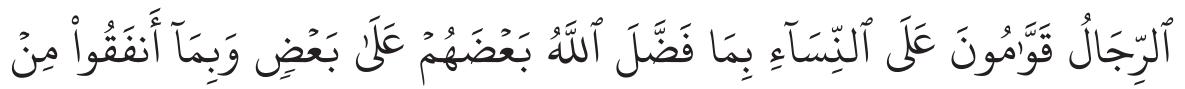

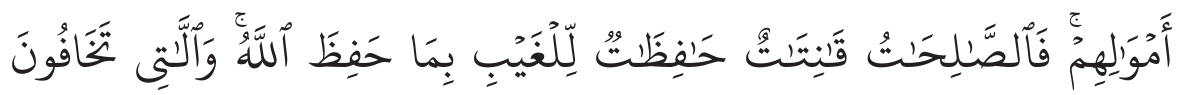

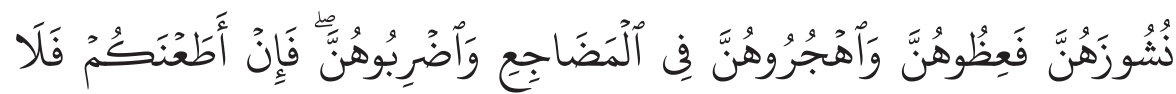

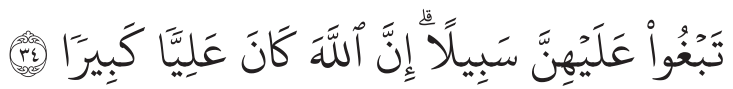

Kaumlaki-laki itu adalah pemimpin bagi kaum wanita, oleh karena Allah telah melebihkan sebahagian mereka (laki-laki) atas sebahagian yang lain (wanita), dan karena mereka (laki-laki) telah menafkahkan sebagian dari harta mereka. sebab itu Maka wanita yang saleh, ialah yang taat kepada Allah lagi memelihara diri[289] ketika suaminya tidak ada, oleh karena Allah telah memelihara (mereka)[290]. wanita-wanita yang kamu khawatirkan nusyuznya[291], Maka nasehatilah mereka dan pisahkanlah mereka di tempat tidur mereka, dan pukullah mereka. kemudian jika mereka mentaatimu, Maka janganlah kamu mencari-cari jalan untuk menyusahkannya[292]. Sesungguhnya Allah Maha Tinggi lagi Maha besar. (QS. An Nisaa':34)

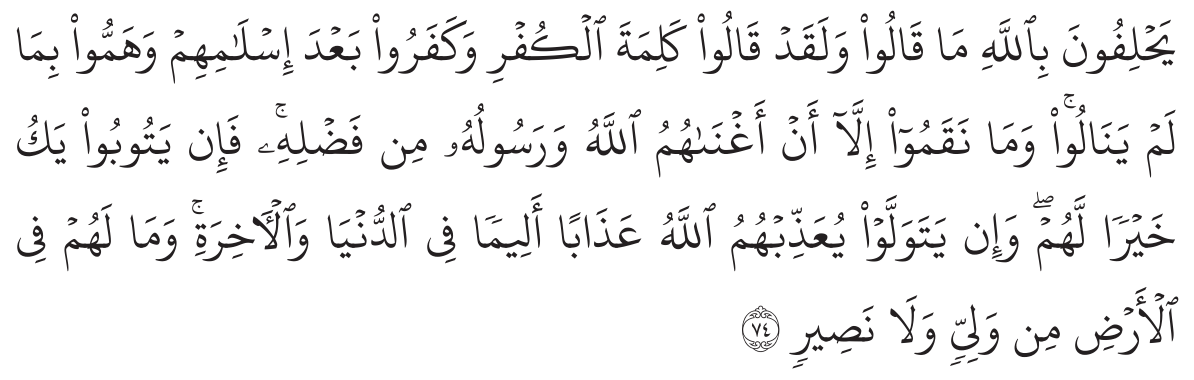

Mereka (orang-orang munafik itu) bersumpah dengan (nama) Allah, bahwa mereka tidakmengatakan (sesuatu yang menyakitimu). Sesungguhnya mereka telah mengucapkan Perkataan kekafiran, dan telah menjadi kafir sesudah Islam dan mengingini apa yang mereka tidak dapat mencapainya[650], dan mereka tidak mencela (Allah dan Rasul-Nya), kecuali karena Allah dan Rasul-Nya telah melimpahkan karunia-Nya kepada mereka. Maka 
jika mereka bertaubat, itu adalah lebih baik bagi mereka, dan jika mereka berpaling, niscaya Allah akan mengazab mereka dengan azab yang pedih di dunia dan akhirat; dan mereka sekali-kali tidaklah mempunyai pelindung dan tidak (pula) penolong di muka bumi. (QS At-Taubah: 74)

\section{Teori Belajar Behavioristik}

\section{Pandangan Teori Behavioristik}

Teori belajar behavioristik adalah sebuah teori yang dicetuskan oleh Gage dan Berliner tentang perubahan tingkah laku sebagai hasil dari pengalaman. ${ }^{8}$ Menurut teori behaviorisme, belajar adalah perubahan tingkah laku sebagai akibat dari adanya interaksi antara stimulus dan respon. Dengan kata lain, belajar merupakan bentuk perubahan yang dialami siswa dalam hal kemampuannya untuk bertingkah laku dengan cara yang baru sebagai hasil interaksi antara stimulus dan respon. Seseorang dianggap telah belajar sesuatu jika ia dapat menunjukkan perubahan tingkah lakunya. ${ }^{9}$

Menurut teori ini yang terpenting adalah masukan atau input yang berupa stimulus dan keluaran atau output yang berupa respons. Stimulus adalah apa saja yang diberikan guru kepada siswa misalnya daftar perkalian, alat peraga, pedoman kerja atau cara-cara tertentu, untuk membantu belajar siswa, sedangkan respons adalah reaksi atau tanggapan siswa terhadap stimulus yang diberikan oleh guru tersebut. ${ }^{10}$

Dalam teori ini tingkah laku dalam belajar akan berubah apabila ada stimulus dan respons. Stimulus dapat berupa perlakuan yang diberikan kepada siswa, sedangkan respons berupa tingkah laku yang terjadi pada siswa. ${ }^{11}$ Faktor lain yang juga dianggap penting oleh aliran behavior adalah faktor pengutan (reinforcement). Penguatan adalah apa saja yang dapat memperkuat timbulnya respon bila pengutan ditambahkan maka respon semakin kuat. Begitu juga bila pengutan dikurangi responpun akan tetap dikuatkan. Misalnya, ketika

\footnotetext{
8 Gage,N.L.,\& Berliner, D.,dalam https://id.wikipedia.org/wiki/Teori_Belajar_Behavioristik\#cite_ note-1

9 C. Asri Budiningsih, Belajar dan Pembelajaran (Jakarta: PT. Rineka Cipta, 2005) h. 21.

10 Ibid

11 M. Sukarjo dan Ukim Komarudin, Landasan Pendidikan (Jakarta: PT. Raja Grafindo Persada, 2012), h.34.
} 
peserta didik diberi tugas oleh guru, ketika tugasnya ditambahkan maka ia akan semakin giat belajarnya. Maka penambahan tugas tersebut merupakan penguat positif (positive reinforcement) dalam brlajar. Bila tugas-tugas dikurangi dan pengurangan itu justru meningkatkan aktifitas belajarnya, maka pengurangan tugas merupakan penguatan negatif (negative reinforcement) dalam belajar. Jadi penguatan merupakan suatu bentuk stimulus yang penting diberikan atau dikurangi untuk memungkinkan terjadinya respon. ${ }^{12}$

\section{Tokoh Teori Behavioristik}

1. Edward Lee Thorndike

Thorndike menyatakan bahwa prilaku belajar manusia ditentukan oleh stimulus yang ada di lingkungan sehingga menimbulkan respon secara refleks. Stimulus yang terjadi setelah sebuah prilaku terjadi akan mempengaruhi prilaku selanjutnya. Dari eksperimen ini Thorndike telah mengembangkan hukum Law Effect. Ini berarti jika sebuah tindakan diikuti oleh sebuah perubahan yang memuskan dalam lingkungan, maka kemungkinan tindakan itu akan diulang kembali akan semakin meningkat. Sebaliknya jika sebuah tindakan diikuti oleh perubahan yang tidak memuaskan, maka tindakan itu menurun atau tidak dilakukan sama sekali. Dengan kata lain, konsekuen-konsekuen dari prilaku sesorang akan memainkan peran penting bagi terjadinya prilaku-prilaku yang akan datang. ${ }^{13}$

Menurut Thorndike, belajar adalah proses interaksi antara stimulus dan respon. Stimulus yaitu apa saja yang dapat merangsang terjadinya kegiatan belajar seperti pikiran, perasaan, atau hal-hal lain yang dapat ditangkap melalui alat indera. Sedangkan respon yaitu reaksi yang dimunculkan peserta didik ketika belajar, yang juga dapat berupa pikiran, perasaan, atau gerakan dan tindakan. ${ }^{14}$

2. Jhon Broadus Waston

Waston adalah seorang tokoh aliran behaviorisme yang datang setelah Thorndike. Menurutnya, belajar adalah proses interaksi antara

12 Zalyana, Psikologi Pembelajaran Bahasa Arab (Pekanbaru: Almujtahadah Press, 2010)hlm. 104-105.

13 Zalyana, Psikologi Pembelajaran Bahasa Arab (Pekanbaru: Almujtahadah Press, 2010), hlm. 113114

14 Asri Budiningsih, Belajar dan Pembelajaran, hlm.21 
stimulus dan respon, namun stimulus dan respo yang dimaksud harus berbentuk tingkah laku yang dapat diamati (observabel) dan dapat diukur. Dengan kata lain, walupun ia mengakui adanya perubahan-perubahan mental dalam diri seseorang selama proses belajar, namun ia menganggap hal-hal tersebut sebagai faktor yang tak perlu diperhitungkan. Ia tetap mengakui bahwa perubahanperubahan mental dalam benak siswa itu penting. Namun semua itu tidak dapat menjelaskan apakah seseorang telah belajar atau belum karena tidak dapat diamati. ${ }^{15}$

3. Clark Hull

Hull berpendirian bahwa tinkah laku itu berfungsi menjaga agar oranisasi tetap bertahan hidup. Konsep sentral dalam teorinya berkisar pada kebutuhan biologis dan pemuas kebutuhan, hal yang penting bagi kelangsungan hidup. Oleh Hull, kebutuhan ddikonsepkan sebagai dorongan (drive) seperti lapar, haus, tidur, hilangnya rasa nyeri, dan sebagainya. Stimulus yang disebut stimulus dorongan dikaitkan dengan dorongan primer dan karena itu mendorong timbulnya tigkah laku. Sebagai contoh, stimulus yang dikaitkan dengan rasa nyeri, seperti bunyi alat pengebor gigi, dapat menimbulkan rasa takut, dan takut itu mendorong timbulnya tingkah laku. ${ }^{16}$

4. Edwin Ray Guthrie

Belajar terjadi karena gerakan terakhir yang dilakukan mengubah situasi stimulus sedangkan tidak ada respon lain yang dapat terjadi. Penguatan hanya sekedar melindungi hasil belajar yang baru agar tidak hilang dengan jalan mencegah perolehan respon yang baru.

Teori guthrie ini mengatakan bahwa hubungan stimulus dan respon bersifat sementara, oleh karenanya dalam kegiatan belajar, peserta didik perlu sesering mungkin diberi stimulus agar hubungan stumulus dan respon bersifat lebih kuat dan menetap. Guthrie juga percaya bahwa hukuman (punishment) memegang peranan penting

15 Ibid., hlm. 22.

16 M. Sukarjo dan Ukim Komarudin, Landasan Pendidikan, hlm.42 
dalam proses belajar. Hukuman yang diberikan pada saat yang tepat akan mampu mengubah tingkah laku seseorang. ${ }^{17}$

5. Burrhus Frederic Skinner

Menurut skinner - berdasarkan percobaanya terhadap tikus dan burung merpati - unsur terpenting dalam belajar adalah penguatan. Maksudnya adalah penguatan yang terbentuk melalui ikatan stimulus respon akan semakin kuat bila diberi penguatan ( penguatan positif dan penguatan negatif). Bentuk penguatan positif berupa hadiah, perilaku, atau penghargaan. Sedangkan bentuk penguatan negatif adalah antara lain menunda atau tidak memberi penghargaan, memberikan tugas tambahan, atau menunjukkan perilaku tidak senang.

Skinner tidak sependapat pada asumsi yang dikemukakan Guthrie bahwa hukuman memegang peranan penting dalam proses pelajar. Hal tersebut dikarenakan menurut skinner :

1) Pengaruh hukuman terhadap perubahan tingkah laku sangat bersifat sementara.

2) Dampak psikologis yang buruk mungkin akan terkondisi (menjadi bagian dari jiwa terhukum) bila hukuman berlangsung lama.

3) Hukuman mendorong si terhukum mencari cara lain (meskipun salah dan buruk) agar ia terbebas dari hukuman.

4) Hukuman dapat mendorong si terhukum melakukan hal-hal lain yang kadangkala lebih buruk dari pada kesalahan pertama yang diperbuatnya. ${ }^{18}$

\section{E. Targhib dan Tarhib Perspektif Teori Belajar Behaviorisme}

Islam telah menempatkan konsep imbalan dan hukuman sebagai prinsip utama dalam pendidikan. Dengan imbalan, anak akan termotivasi untuk melakukan kebaikan, dan dengan hukuman, anak akan berhati-hati agar

17 Zalyana, Psikologi Pembelajaran Bahasa Arab, hlm.123

18 Asri Budiningsih, Belajar dan Pembelajaran, hlm.25-26 
tidak terjerumus pada keburukan. ${ }^{19}$ Pandangan ini agaknya mempunyai arah yang sama dengan pemikiran skinner dalam salah satu pernyataannya "setiap konsekuensi atau dampak tingkah laku memperkuat tingkah laku tertentu". Pernyataan Skinner memberikan penjelasan bahwa, konskwensi yang akan akan diperoleh seseorang ketika melakukan sesuatu yang telah tergambarkan dari ancaman ataupun hadiah dalam ayat-ayat Al Qur'an akan memberikan dampak kepada pengarahan perilaku. Dalam hal ini, Al Qur'an bermaksud mengarahkan manusia untuk berjalan dalam jalan yang lurus dengan mengikuti petunjuk-petunjuknyaNya dengan cara memberikan motivasi melalui janji akan adanya hadiah dan ancaman. Konsep ini juga sejalan dengan pandangan Clark Hull mengenai gambaran-gambaran kesenangan dan kenikmatan yang dijanjikan kepada manusia merupakan pemuasan kebutuhan biologis manusia seperti, adanya Syurga yang mengalir air mata, aneka buah-buahan, bahkan bidadari-bidadari cantik sebagai imbalan akan keshlehan manusia.

Dalam konteks mendidik, menurut al-Ghazali hendaknya para guru memberikan nasehat kepada siswanya dengan kelembutan. Guru di tuntut berperan sabagai orang tua yang dapat merasakan apa yang dirasakan anak didiknya, jika anak memperlihatkan suatu kemajuan, seyogianya guru memuji hasil usaha muridnya, berterima kasih padanya, dan mendukungnya terutama didepan teman-temannya. Guru perlu menempuh prosedur yang berjenjang dalam mendidik dan menghukum anak saat dia melakukan kesalahan.

Ibn Khaldun mengemukakan masalah imbalan dan hukuman dengan menyebutkan selain seorang pendidik harus mengetahui cara pertumbuhan akal manusia yang bertahap hingga ia mampu mensejalankan pertumbuhan itu dengan pengajarannya terhadap anak didik. Ia menasehatkan agar tidak kasar dalam memperlakukan anak didik yang masih kecil, mencubit tubuh dalam pengajaran merusak anak didik, khususnya anak kecil.

Perlakuan kasar dan keras terhadap anak kecil dapat menyebabkan kemalasan dan mendorong mereka untuk berbohong serta memalingkan diri dari ilmu dan pengajaran. Oleh karena itu pendidik harus memperlakukan anak didik dengan kelembutan dan kasih sayang serta tegas dalam waktu-

19 Ahmad Ali Budaiwi, Imbalan dan Hukuman dan Pengaruhnya bagi Pendidikan Anak, (Jakarta: Gema Insani Press, 2002), hlm.V 
waktu yang diutuhkan untuk itu.Lebih lanjut, M. Arifin memberi pengertian hukuman adalah: "Pemberi rasa nestapa pada diri anak akibat dari kelasahan perbuatan atau tingkah laku anak menjadi sesuai dengan tata nilai yang diberlakukan dalam lingkungannya. ${ }^{\text {"no }}$

Pandangan-pandangan tersebut diatas sesuai dengan penggunaan istilah "hukuman" yang tidak dipakai oleh Skinner, tetapi menggunakan istilah "penguatan" atau reinforcement. Skinner tidak begitu memberikan perhatian terhadap hukuman sebagai cara yang efektif dalam mendidik anak, tetapi menggunakan metode negative reinforcement. Perbedaannya adalah, jika metode hukuman akan memberikan tambahan hukuman apabila anak melakukan kesalahan, sedang penguatan negatif dilakukan dengan cara mengurangi beban yang sulit untuk dikerjakan oleh seseorang sehingga melakukan kesalahan. Asumsi reinforcement adalah individu akan mengulangi suatu perbuatan jika perbuatan tersebut menyenangkan, dan individu akan meninggalkan suatu perbuatan apabila perbuatan tersebut berakibat menyakitkan.

Syamsu yusuf mengartikan reinforcement sebagai "peneguhan", dimana peneguhan ini dibagi menjadi dua macam, yakni: 1. Peneguhan (Reinforcement) positif, yaitu suatu rangsangan (stimulus) yang memperkuat atau mendorong suatu respon (tingkah laku tertentu). Peneguhan positif ini bebrentuk reward (ganjaran, hadiah, atau imbalan), baik secara verbal (kata-kata atau ucapan pujian) maupun non verbal (isyarat, senyuman, hadiah berupa benda-benda dan makanan). 2. Peneguhan (Reinforcement) negative, yaitu suatu rangsangan (stimulus) yang mendorong seseorang untuk menghindari respon tertentu yang konsekuensi atau dampaknya tidak memuaskan (menyakitkan atau tidak menyenangkan). Peneguhan ini bentuknya berupa hukuman (punishment) atau pengalaman yang tidak menyenangkan. ${ }^{21}$

Istilah reward dan punishment merupakan satu rangkaian yang dihubungkan dengan pembahasan reinforcement yang diperkenalkan oleh Thorndike dalam observasinya tentang trial-and eror sebagai landasan

20 M. Arifin, Ilmu Pendidikan Suatu Tinjauan Teoritis dan Praktis (rev. ed.: Bandung, 1994), hal. 175176

21 Syamsu yusuf, Psikologi Belajar Agama(Perspektif Pendidikan Agama Islam), (Bandung: Pustaka Bani Quraisy, 2005), hlm. 115-116 
utama reinforcement (dorongan, dukungan). Dengan adanya reinforcement tingkah laku atau perbuatan individu semakin menguat, sebaliknya dengan absennya reinforcement tingkah laku tersebut semakin melemah. ${ }^{22}$ Dalam dunia pendidikan, reward digunakan sebagai bentuk motivasi atau sebuah penghargaan untuk hasil atau prestasi yang baik, dapat berupa kata-kata pujian, pandangan senyuman, pemberian tepukan tangan serta sesuatu yang menyenangkan anak didik, misalnya pemberian beasiswa bagi yang telah mendapat nilai bagus.

Namun sejatinya, kendatipun menurut teori belajar behavioristik dapat diambil suatu hubungan kausal antara janji (targhib dan tarhib) sebagai stimulus, dan perilaku manusia sebagai respon, dengan tujuan pembinaan perilaku atau akhlak manusia yang baik (akhlaqul karimah), dalam Al Qur'an ada nilai yang lebih tinggi yang melampaui sekedar dimensi duniawi, yaitu bahwa keimanan terhadap Allah SWT memberikan konskwensi pada keimanan terhadap hari akhir dimana janji-janji yang termaktub dalam targhib dan tarhib ayat-ayat Al Qur'an bersifat haq. Nahlawi menyatakan bahwa berbeda dari metode ganjaran dan hukuman dalam pendidikan barat. Perbedaan yang paling mendasar adalah targhib dan tarhib berdasarkan ajaran Allah SWT. yang sudah pasti kebenarannya, sedangkan ganjaran dan hukuman berdasarkan pertimbangan duniawi yang terkadang tidak lepas dari ambisi pribadi. ${ }^{23}$

\section{F. Kesimpulan}

Al Qur'an menggunakan Targhib dan Tarhib untuk membangkitkan motivasi agar beriman kepada Allah dan rasulnya, mengikuti ajaran Islam, melaksanakan ibadah wajib, menjauhi maksiat dan hal yang dilarang oleh Allah dan berpegang pada istiqomah dan takwa.Targhib adalah janji akan suatu imbalan yang bersifat memberikan maslahah, kenikmatan, dan menyenangkan sebagai ganjaran atas amal shaleh manusia. Sedangkan Tarhib adalah janji yang berupa ancaman yang menyakitkan dan pedih dengan

22 Sumanto. Metodologi penelitian Sosial dan Pendidikan.(Yogyakarta: Andi Offset, 1990), hlm. 117

23 Abd.al Rahman al Nahlawi. Usul al Tarbiyah al Islamiyah wa Asalibuha fi al bayt wa al madrasah wa al mujtama, (Beirut, Daar al Fikri 2001), hlm 287. 
memperlihatkan kebesaran dan keMaha Kuasaan Allah agar manusia tidak melakukan kesalahan di dunia dengan melanggar aturan-atuan yang telah ditetapkanNya

Menurut teori belajar behavioristik, yang mempengaruhi perilaku seseorang yang terpenting adalah masukan atau input yang berupa stimulus dan keluaran atau output yang berupa respons. Stimulus adalah apa saja yang diberikan guru kepada siswa misalnya daftar perkalian, alat peraga, pedoman kerja atau cara-cara tertentu, untuk membantu belajar siswa, sedangkan respons adalah reaksi atau tanggapan siswa terhadap stimulus yang diberikan oleh guru tersebut.

Islam telah menempatkan konsep imbalan dan hukuman sebagai prinsip utama dalam pendidikan. Dengan imbalan, anak akan termotivasi untuk melakukan kebaikan, dan dengan hukuman, anak akan berhati-hati agar tidak terjerumus pada keburukan. Pandangan ini agaknya mempunyai arah yang sama dengan pemikiran teosri belajar behaviorisme sebagaimana skinner dalam salah satu pernyataannya "setiap konsekuensi atau dampak tingkah laku memperkuat tingkah laku tertentu”. Pernyataan Skinner memberikan penjelasan bahwa, konskwensi yang akan akan diperoleh seseorang ketika melakukan sesuatu yang telah tergambarkan dari ancaman ataupun hadiah dalam ayat-ayat Al Qur'an akan memberikan dampak kepada pengarahan perilaku. Dalam hal ini, Al Qur'an bermaksud mengarahkan manusia untuk berjalan dalam jalan yang lurus dengan mengikuti petunjuk-petunjuknyaNya dengan cara memberikan motivasi melalui janji akan adanya hadiah dan ancaman.

\section{DAFTAR PUSTAKA}

Abdurrahman an-Nahlawi, Ushulut Tarbiyatil Islamiyah wa Aslibuha, terj. Herry Noer Ali, Prinsip-prinsip dan metode Pendidikan Islam,( Bandung : Diponegoro, 1992).

Ahmad Ali Budaiwi, Imbalan dan Hukuman dan Pengaruhnya bagi Pendidikan Anak, (Jakarta: Gema Insani Press, 2002).

Asri Budiningsih, Belajar dan Pembelajaran (Jakarta: PT. Rineka Cipta, 2005). 
Gage,N.L.,\& Berliner, D., dalam https://id.wikipedia.org/wiki /Teori_ Belajar_Behavioristik\#cite_note-1, diunduh pada Ahad, 10 Januari 2016 Jam 19.00.

Muhammad Thalib, Pendidikan Islam metode 30 T, (Bandung : Irsyad Baitus Salam 1996)

Muhammad Usman Najati, Belajar EQ dan SQ dari Sunnah Nabi, Terj. Irfan Salim, (Jakarta : Hikmah, 2002)

M. Sukarjo dan Ukim Komarudin, Landasan Pendidikan (Jakarta: PT. Raja Grafindo Persada, 2012)

M. Arifin, Ilmu Pendidikan Suatu Tinjauan Teoritis dan Praktis (rev. ed.: Bandung, 1994).

Sumanto, Metodologi penelitian Sosial dan Pendidikan,(Yogyakarta: Andi Offset, 1990).

Syamsu Yusuf, Psikologi Belajar Agama(Perspektif Pendidikan Agama Islam), (Bandung: Pustaka Bani Quraisy, 2005)

Syahidin, Metode Pendidikan Qur'ani Teori dan Aflikasi, (Jakarta, Misaka galiza, 1999)

Zalyana, Psikologi Pembelajaran Bahasa Arab (Pekanbaru: Almujtahadah Press, 2010) 